\title{
Development and Application of a Multiplex Reverse-Transcription Polymerase Chain Reaction Assay for Screening a Global Collection of Citrus tristeza virus Isolates
}

\author{
Avijit Roy, G. Ananthakrishnan, John S. Hartung, and R. H. Brlansky
}

First, second, and fourth authors: University of Florida, IFAS, Citrus Research and Education Center, Plant Pathology, 700 Experiment Station Road, Lake Alfred 33850-2299; and third author: United States Department of Agriculture-Agricultural Research Service, MPPL, Beltsville, MD.

Accepted for publication 7 June 2010.

\begin{abstract}
Roy, A., Ananthakrishnan, G., Hartung, J. S., and Brlansky, R. H. 2010. Development and application of a multiplex reverse transcription polymerase chain reaction assay for screening a global collection of Citrus tristeza virus isolates. Phytopathology 100:1077-1088.

The emerging diversity of Citrus tristeza virus (CTV) genotypes has complicated detection and diagnostic measures and prompted the search for new differentiation methods. To simplify the identification and differentiation of CTV genotypes, a multiplex reverse-transcription polymerase chain reaction (RT-PCR) technique for the screening of CTV isolates was developed. Variable regions within the open reading frame (ORF)-1a of diverse CTV genotypes were identified to develop first a simplex (S) and then a hexaplex (H) RT-PCR. CTV isolates have been grouped previously into five genotypes (namely, T3, T30, T36, VT, and B165) based on the nucleotide sequence comparisons and phylogenetic analyses. Nucleotide sequences from GenBank were used to design species and genotype-specific primers (GSPs). The GSPs were initially

thermore, detection of all five recognized CTV genotypes was established using the H-RT-PCR. Six amplicons, one generic to all CTV isolates and one for each of the five recognized genotypes, were identified on the basis of their size and were confirmed by sequence analysis. In all, 175 CTV isolates from 29 citrus-growing countries were successfully analyzed by S- and H-RT-PCR. Of these, 97 isolates contained T36 genotypes, 95 contained T3 genotypes, 76 contained T30 genotypes, 71 contained VT genotypes, and 24 contained B165 genotype isolates. In total, 126 isolates contained mixed infections of 2 to 5 of the known CTV genotypes. Two of the CTV isolates could not be assigned to a known genotype. H-RT-PCR provides a sensitive, specific, reliable, and rapid way to screen for CTV genotypes compared with other methods for CTV genotype detection. Efficient identification of CTV genotypes will facilitate a better understanding of CTV isolates, including the possible interaction of different genotypes in causing or preventing diseases. The methods described can also be used in virus-free citrus propagation programs and in the development of CTV-resistant cultivars.
\end{abstract} used for reliable detection of all CTV genotypes using S-RT-PCR. Fur-
Citrus spp. are hosts for various virus and virus-like pathogens. One of these, Citrus tristeza virus (CTV), is an aphid-transmitted, phloem-limited virus that belongs to the family Closteroviridae and, for the past 80 years, CTV has been the most economically important viral pathogen of Citrus spp. $(6,27)$. CTV has a host range restricted to two genera within the family Rutaceae $(27,35)$. The virus is usually introduced into new citrus-growing areas by propagation of infected budwood and is then spread by aphids in a semipersistent mode (23). CTV may be present in infected trees singly or in mixtures of genotypes $(2,9,38)$.

CTV infection may cause different disease symptoms. Due to the wide biological diversity of CTV, identification of the actual virus genotype or genotypes present in an area is essential to determine control strategies. An isolate of CTV usually falls into one or more of the general biological symptom categories as previously defined $(13,34)$. These biological symptoms are as follows: leaf reaction (LR) on Mexican lime, decline of sweet orange on sour orange (DEC), seedling yellows on sour orange seedlings (SO-SY), or stem pitting on either grapefruit (GFSP) or sweet orange (OSP) (13). All symptoms can be rated (0-to-3

Corresponding author: R. H. Brlansky; E-mail address: rhby@crec.ifas.ufl.edu

* The $\boldsymbol{e}$-Xtra logo stands for "electronic extra" and indicates that Figure 1 appears in color online.

doi:10.1094/PHYTO-04-10-0102

(C) 2010 The American Phytopathological Society scale, with 0 indicating no symptoms, 1 indicating mild symptoms, 2 indicating moderate symptoms, and 3 indicating a very severe reaction) and an isolate having a certain rating on each indicator can be placed in a certain pattern number (0-to-10) (13). The LR in Mexican lime is rated depending on the amount of vein clearing, leaf cupping, stunting, and stem pitting in the host. The DEC syndrome is rated as the amount of stunting and leaf chlorosis of sweet orange grafted on sour orange, indicative of CTV-induced bud-union phloem injury. The SO-SY reaction is characterized by chlorotic leaves, reduced leaf size, and stunting of sour orange seedlings. GFSP and OSP are the stem pitting reactions of Duncan grapefruit and Madam Vinous sweet orange seedlings, respectively. The name "stem pitting" indicates the presence of longitudinal pits or channels in the wood of the stems.

Several techniques have been developed for the detection and differentiation of CTV isolates. Traditionally, CTV has been detected and categorized by biological indexing, which requires inoculation of appropriate indicator plants $(13,14)$. Following the purification of CTV, antibodies to the virus and associated serological tests were developed. These procedures include enzyme-linked immunosorbent assay (ELISA) and direct tissue-blot immunoassay (DTBIA) (15) using a variety of polyclonal and monoclonal antibodies (MAbs) $(31,33,51)$. The most widely used MAb to distinguish mild and DEC isolates is MCA13 (33), which detects only decline strains. ELISA and DTBIA are reliable and rapid and have relatively low costs but their main drawbacks are sensitivity and specificity (47). With the advance of methods from 
molecular biology, reverse-transcription polymerase chain reaction (RT-PCR) has been adapted for detection of CTV. Specific RT-PCR assays for different genomic regions that distinguished different CTV isolates by genotype have been previously developed $(3,17-20,32,41,46)$. Single-strand conformation polymorphism (SSCP) analysis also has been used to characterize the genetically diverse population structure of CTV $(4,38,42,46)$. More recently, reverse-transcription quantitative polymerase chain reaction (RT-qPCR) has been developed for detection and quantification of CTV from infected tissue and aphids $(2,7,43,47)$. Rapid identification of mild, DEC, SY, or SP CTV isolates has been accomplished by a highly specific RT-qPCR method using TaqMan locked nucleic acids probes (44).

Multiplex RT-PCR is a useful technique for detecting multiple viruses infecting citrus $(40)$ and other plants $(8,11,12,45,50)$. This sensitive technique should be very useful for identification of multiple CTV genotypes, as has been done in potato, where a competitive multiplex RT-PCR was developed using single antisense and multiple strain-specific sense primers to distinguish biologically and geographically distinct strains of Potato virus $Y$ infecting potato $(24,29,30)$.

Five CTV genotype isolates (T3, T30, T36, VT, and B165) have now been described and characterized $(1,16,22,25,39)$. The biological characteristics and relative nucleotide homologies (complete and open reading frame [ORF]1a) of the five CTV type isolates are described in Table 1. In this study, a set of genotypespecific sense and antisense primers was developed and applied using simplex (S) and multiplex RT-PCR to test a global collection of 175 CTV isolates from the United States and other citrus-producing countries. This is the first use of multiplex RTPCR for the simultaneous detection of the five known CTV genotypes from infected citrus plants.

\section{MATERIALS AND METHODS}

Virus isolates used as positive controls. The CTV genotypic isolates T3, T30, T36, VT, and B165 were used as positive controls in this study. Type isolates T3, T30, and T36 were collected from greenhouse plant materials at the University of Florida, Citrus Research and Education Center (CREC), Lake Alfred. The VT (B395) and B165 isolates were collected from the Exotic Pathogens of Citrus Collection (EPCC), Beltsville, MD. Isolates were selected for screening based on geographical and biological properties. All of the EPCC isolates were designated with a prefix " $\mathrm{B}$ ". All virus isolates were maintained in Mexican lime (Citrus aurantifolia (Christm.) Swingle) or Madam vinous sweet orange (C. sinensis (L.) Osbeck) seedlings. Healthy Mexican lime and Madam Vinous seedlings were used as negative controls for all experiments. Other CTV isolates used as positive controls were isolate FS317 (mixture of T30 and T36 genotypes), isolate FS627 (T30, T36, and VT genotypes), graft-inoculated mixture of isolates FS627 and B408 (T3, T30, T36, and VT genotypes), and isolates FS627 and T68 (T3, T30, T36, VT, and B165 genotypes).

Isolation of total RNA from citrus tissues. Phloem-containing citrus bark tissues $(100 \mathrm{mg})$ were removed from trees and either dried over silica gel or used fresh as starting materials for extraction of RNA. The Qiagen RNeasy plant mini kit (catalog no. 74904; Valencia, CA) and TRIzol from Invitrogen (catalog no. 15596-026; Carlsbad, CA) were used to prepare total RNA containing CTV genomic targets to compare the yield and purity of the extracted RNA. Estimation of RNA yield and quality was done with a NanoDrop ND-1000 Spectrophotometer (Wilmington, DE) by measuring optical density at $260 \mathrm{~nm}$ and the ratio of the absorbance at 260 and $280 \mathrm{~nm}$, respectively.

Species and genotype-specific CTV primers. Six sets of primers were designed for S- and hexaplex (H) RT-PCR to amplify the following areas of the CTV genome: (i) the conserved areas within the coat protein gene (CPG), (ii) a portion of the large interdomain region (IDR) of isolate NZ-M16 (a T3-like isolate), (iii) a partial portion of the leader protease (LPro) I domain of ORF1a of the T30 isolate, and (iv) the LProII domain encoding a portion of ORF1a, an area conserved in type isolates T36, VT, and B165. The CPG primers were used for detection of all CTV genotypes. The sequence information for the genotypespecific primers (GSPs) was obtained from the 12 complete nucleotide sequences of CTV isolates: B165 (accession EU076703), NZ-B18 (FJ525436), NZ-M16 (EU857538), T318A (DQ151548), NUagA (AB046398), VT (U56902), SY568 (AF001623), T30 (AF260651), T385 (Y18420), T36 (U16304), Qaha (AY340974), and an isolate from Mexico (DQ272579) available from the National Center for Biotechnology Information (NCBI) database (http://www.ncbi.nlm.nih.gov). The sequences available of CTV isolates were aligned using the multiple alignment analysis program CLUSTAL-X (49) followed by GeneDoc (28). Criteria such as specificity, stability, and compatibility were considered in the primer design. The program Oligo Analyzer 3.1 (Integrated DNA Technology) was then used (http://www. idtdna.com) to determine the annealing temperatures for the sense and antisense GSPs. The oligonucleotide sequences were also scanned for internal structures such as hairpins and self and hetero dimers using the MFOLD program in Oligo Analyzer 3.1. The GSPs for isolates T3, T30, T36, VT, B165, and the speciesspecific CPG RT-PCR primers are listed in Table 2.

Standardization of S-RT-PCR. The first strand of cDNA synthesis was accomplished using $10 \mu \mathrm{l}$ of total RNA at $200 \mathrm{ng} / \mu \mathrm{l}$, $10 \mu \mathrm{M}$ species- and genotype-specific antisense primer, $10 \mathrm{mM}$ dNTP, $5 \times$ first-strand buffer, 0.1 M dithiothreitol, r-RNasin (Promega Corp., Madison, WI), and Superscript II RT (Invitrogen) as per the manufacturer's protocol. The tubes were then incubated at

TABLE 1. Comparison of five identifiable Citrus tristeza virus genotypes based on their symptoms and nucleotide sequence identity

\begin{tabular}{|c|c|c|c|c|c|c|c|c|c|c|c|}
\hline \multirow[b]{2}{*}{ Isolate $^{a}$} & \multicolumn{5}{|c|}{ Symptoms ${ }^{\mathrm{b}}$} & \multirow[b]{2}{*}{ Genotype } & \multicolumn{5}{|c|}{ Nucleotide sequence homology $(\%)^{\mathrm{c}}$} \\
\hline & LR & DEC & SO-SY & GFSP & OSP & & I & II & III & IV & $\mathrm{V}$ \\
\hline T36 (U16304) & ++ & ++++ & ++ & - & - & $\mathrm{I}$ & $\ldots$ & $80-81$ & $78-80$ & $78-79$ & 79 \\
\hline T30 (AF260651) & + & - & - & - & - & II & $71-72$ & $\ldots$ & 89-93 & 86 & 89 \\
\hline VT (U56902) & ++++ & + & + & + & +++ & III & $70-72$ & $89-90$ & $\ldots$ & $88-90$ & $90-93$ \\
\hline B165 (EU076703) & +++ & +++ & ++ & - & +++ & IV & $71-72$ & 84 & $84-86$ & $\ldots$ & 88 \\
\hline $\mathrm{T} 3{\text { (EU } 857538)^{\mathrm{d}}}^{\prime}$ & +++ & ++ & + & ++ & ++++ & $\mathrm{V}$ & $71-72$ & 90 & 89-91 & $83-84$ & $\ldots$ \\
\hline
\end{tabular}

a Type isolate of each genogroup and GenBank accession.

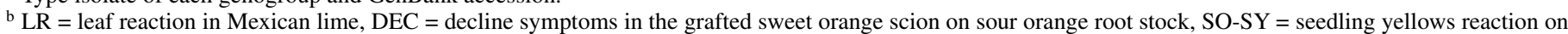
sour orange seedlings, GFSP = grapefruit stem pitting on Duncan cultivar seedlings, and OSP = sweet orange stem pitting on Madam Vinous cultivar seedlings. All the isolates symptoms were according to Garnsey et al. (14); + sign indicates the presence of specific symptom and increasing number of + signs indicates the level of severity of infection.

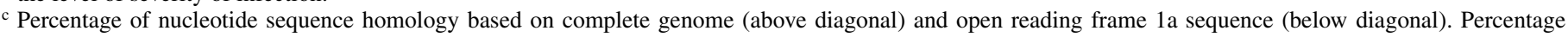
(except T3 genotype) was according to Roy and Brlansky (39).

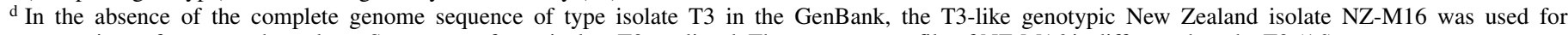
comparison of sequence homology. Symptoms of type isolate T3 are listed. The symptom profile of NZ-M16 is different than the T3 (16). 
$42^{\circ} \mathrm{C}$ for $50 \mathrm{~min}$ followed by inactivation of the reaction by heating at $70^{\circ} \mathrm{C}$ for $15 \mathrm{~min}$ in a thermal cycler (Model HBPX 110; PCR Express, Hybaid Limited, Middlesex, UK). The GoTaq Green Master Mix (catalog no. M7123; Promega Corp.) was used for the standard-format PCR assay. A 3.0- $\mu$ l sample of amplified cDNA was used as template in a PCR reaction (50- $\mu$ l volume) following the protocol described by Roy et al. (40). To determine the best annealing temperature, a gradient PCR was performed using the following parameters: one cycle at $94^{\circ} \mathrm{C}$ for $3 \mathrm{~min} ; 30$ cycles at $94^{\circ} \mathrm{C}$ for $30 \mathrm{~s}, 54$ to $62^{\circ} \mathrm{C}$ for $30 \mathrm{~s}$, and $72^{\circ} \mathrm{C}$ for $45 \mathrm{~s}$; followed by one cycle at $72^{\circ} \mathrm{C}$ for $10 \mathrm{~min}$. The PCR products were analyzed by electrophoresis on $1.0 \%$ agarose gel stained with GelRed (catalog no. 41003; Biotium, Hayward, CA). Amplicons of the expected sizes were produced without any primer dimers to complete standardization of the S-RT-PCR reaction conditions.

Standardization of multiplex RT-PCR. A $10 \times$ primer mixture containing the genotype-specific antisense primers $(2 \mu \mathrm{M}$ each primer) for each of the genotypic isolates was prepared and used to accomplish cDNA synthesis as the first step of the multiplex RT-PCR standardization. For each RT reaction, total RNA at $200 \mathrm{ng} / \mu \mathrm{l}$ from the different CTV isolates was mixed with $10 \mu \mathrm{l}$ of the $10 \times$ antisense primers mixture. The cDNA synthesis protocol developed for S-RT-PCR was used for multiplex RT-PCR in a total reaction volume of $100 \mu \mathrm{l}$. During assay development, a QIAquick PCR purification kit (Qiagen) was used to purify the cDNA which was eluted in $50 \mu$ l of the supplied Qiagen EB buffer. The Multiplex PCR Master Mix $(25 \mu \mathrm{l})$ (catalog no. 206143; Qiagen) was combined with 4 to $5 \mu$ l of eluted cDNA and $5 \mu \mathrm{l}$ of $10 \times$ forward and antisense primers mixture $(2 \mu \mathrm{M}$ of each primer) and adjusted to a 50- $\mu$ l final volume with nucleasefree water. Gradient PCR was used to determine the annealing temperature for all six amplicons as follows: a one-cycle activation step at $95^{\circ} \mathrm{C}$ for $15 \mathrm{~min}$ to activate the HotStar Taq Polymerase; 30 cycles at $94^{\circ} \mathrm{C}$ for $30 \mathrm{~s}, 54$ to $62^{\circ} \mathrm{C}$ for $90 \mathrm{~s}$, and $72^{\circ} \mathrm{C}$ for $90 \mathrm{~s}$; followed by one cycle at $72^{\circ} \mathrm{C}$ for $10 \mathrm{~min}$. The amplified products were analyzed by electrophoresis on a $1.2 \%$ agarose gel.

Sensitivity and applicability of the S- and H-RT-PCR. To evaluate the detection limits of S- and H-RT-PCR, total RNA was isolated from healthy seedlings, plants infected with each of the genotype isolates, and plants with mixed infections. The concentrations of the isolated total RNAs were adjusted to $200 \mathrm{ng} / \mu \mathrm{l}$. Total RNA from five single-genotype isolates was used for the SRT-PCR. In each test, total RNA from a healthy citrus plant was used as the negative control. The cDNA for the CPG and for the five specific genotypes was synthesized using RNA isolated from CTV-infected plants and serially diluted 10 -fold $\left(10^{-1}\right.$ to $\left.10^{-6}\right)$ in nuclease-free water. The 10 -fold dilution series was tested to check the sensitivity of S-RT-PCR. The RNAs from the five single-genotype isolates were mixed together to use as templates for RT-PCR reactions and the resulting cDNA was used to prepare a dilution series that was tested using H-RT-PCR. In addition, cDNA from plants with mixed-genotype infections and pooled cDNA from single-genotype-infected plants were also used to assess the sensitivity and utility of the H-RT-PCR for detecting mixed CTV field infections.

Agarose gel purification and sequence verification. The Qiagen gel extraction kit (catalog no. 28704) was used to purify gel products after electrophoresis. Each individual amplicon from the H-RT-PCR was cut out of the gel, purified, and used as a DNA template for further PCR amplification. The CPGs (positive CTV control) and GSPs were used to confirm the identity of each virus genotype by S-RT-PCR. The PCR products were purified by QIAquick PCR purification kit (catalog no. 28104) and sequencing was done using each GSP pair in both orientations using the ABI Prism BigDye terminator cycle sequencing protocols (Applied Biosystems, Perkin-Elmer Corp., Foster City, CA).

Application of S- and H-RT-PCR for the screening of domestic and exotic CTV isolates. To determine the presence of the various CTV genotypes, 175 isolates from 29 countries representing six continents were screened. These isolates included a total of $24 \mathrm{CTV}$ isolates from California, Texas, and Hawaii; 60 isolates from Florida; and 91 isolates from various citrus-growing countries. Apart from the Florida and Texas CTV isolates, all other U.S. and "exotic" CTV isolates were collected from the EPCC, Beltsville, MD.

\section{RESULTS}

Comparison between the TRIzol reagent and Qiagen RNeasy plant mini-kit for nucleic acid extractions. Highquality RNA was obtained using both the extraction methods. In both S- and H-RT-PCR, consistent amplification products of the expected size were obtained. The RNeasy kits provided a fast and simple method for preparing high concentration of total RNA for use in RT-PCR downstream application and the processing of multiple samples in less than 30 min. Because the Qiagen RNeasy kits were more convenient, all the experimental results below were obtained using them.

Primer design for detection of multiple CTV genotypes using S- and H-RT-PCR. Twelve complete genome sequences of CTV isolates in GenBank were aligned and compared to determine the conserved regions specific to each genotype. Three regions of ORF1a of the CTV genome were selected as targets for the five GSPs. A conserved nucleotide sequence within the LProI domain of the T30 genotype was selected for developing the sense and antisense primers for this genotype. Similarly, genotype-specific conserved regions of the LProII domain were

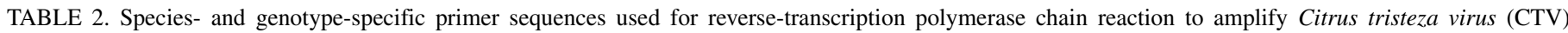
isolates genomic RNA

\begin{tabular}{|c|c|c|c|c|c|c|c|c|}
\hline $\begin{array}{l}\text { CTV } \\
\text { genotype }\end{array}$ & Polarity & Primer sequences from $5^{\prime}$ to $3^{\prime a}$ & $\begin{array}{l}\text { Length } \\
\text { (bp) }\end{array}$ & $\begin{array}{c}\text { Melting } \\
\text { temperature }\left({ }^{\circ} \mathrm{C}\right)\end{array}$ & $\begin{array}{c}\text { GC content } \\
(\%)\end{array}$ & $\begin{array}{c}\text { Accession } \\
\text { no. }\end{array}$ & $\begin{array}{l}\text { Nucleotide } \\
\text { position }\end{array}$ & $\begin{array}{l}\text { Product size } \\
\text { (nucleotides) }\end{array}$ \\
\hline \multirow[t]{2}{*}{ T36 } & Sense & TTC CCT AGG TCG GAT CCC GAG TAT A & 25 & 59.9 & 52.0 & U16304 & $1,775-1,799$ & 836 \\
\hline & Antisense & CAA ACC GGG AAG TGA CAC ACT TGT TA & 26 & 59.2 & 46.2 & $\ldots$ & $2,585-2,610$ & $\ldots$ \\
\hline \multirow[t]{2}{*}{ Generic } & Sense & ATG GAC GAC GAR ACA AAG AAA TTG AAG A & 28 & 57.8 & 37.5 & EU076703 & $16,105-16,132$ & 672 \\
\hline & Antisense & TCA ACG TGT GTT RAA TTT CCC AAG CT & 26 & 58.4 & 40.4 & $\ldots$ & $16,751-16,776$ & 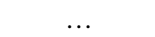 \\
\hline \multirow[t]{2}{*}{ B165 } & Sense & GTT AAG AAG GAT CAC CAT CTT GAC GTT GA & 29 & 58.4 & 41.4 & EU076703 & $2,124-2,152$ & 510 \\
\hline & Antisense & AAA ATG CAC TGT AAC AAG ACC CGA CTC & 27 & 59.2 & 44.4 & $\ldots$ & $2,607-2,633$ & $\ldots$ \\
\hline \multirow[t]{2}{*}{$\mathrm{T}^{\mathrm{b}}$} & Sense & GTT ATC ACG CCT AAA GTT TGG TAC CAC T & 28 & 58.7 & 42.9 & EU857538 & $4,846-4,873$ & 409 \\
\hline & Antisense & CAT GAC ATC GAA GAT AGC CGA AGC & 24 & 57.7 & 50.0 & $\ldots$ & $5,231-5,254$ & $\ldots$ \\
\hline \multirow[t]{2}{*}{ VT } & Sense & TTT GAA AAT GGT GAT GAT TTC GCC GTC A & 28 & 59.5 & 39.3 & U56902 & $1,945-1,972$ & 302 \\
\hline & Antisense & GAC ACC GGA ACT GCY TGA ACA GAA T & 25 & 60.2 & 50.0 & $\cdots$ & $2,222-2,246$ & $\cdots$ \\
\hline \multirow[t]{2}{*}{ T30 } & Sense & TGT TGC GAA ACT AGT TGA CCC TAC TG & 26 & 58.7 & 46.2 & AF260651 & $588-613$ & 206 \\
\hline & Antisense & TAG TGG GCA GAG TGC CAA AAG AGA T & 25 & 60.1 & 48.0 & $\ldots$ & $769-793$ & $\ldots$ \\
\hline
\end{tabular}

a In degenerate primer sequences, the " $\mathrm{R}$ " represents the letters $\mathrm{A}$ or $\mathrm{G}$ and " $\mathrm{Y}$ " represents the letters $\mathrm{C}$ or $\mathrm{T}$.

${ }^{b}$ In the absence of a T3 full-genome sequence in the GenBank, the T3-like genotypic New Zealand isolate NZ-M16 sequence was used. 
selected as targets to develop primers specific for the T36, VT, and B165 genotypes. The IDR of ORF1a was chosen as a target for primers for T3 genotype-specific detection. The target positions and the amplicon sizes of the sense and antisense primers are schematically presented in Figure 1 . Within the regions targeted for amplification, primers were designed based on the following criteria: primer length ( $\approx 25$ nucleotides [nt]), GC content (40 to $50 \%$ ), size differences of genotype-specific amplicons to facilitate screening by electrophoresis $(\approx 100 \mathrm{nt})$, and minimal melting temperature differences between all primers to facilitate the multiplexing of the PCR reaction (not $>3^{\circ} \mathrm{C}$ ) (Table 2). All sense and antisense GSPs were designed across base mismatches to minimize the risk of amplifying nontarget genotypes (Fig. 2).

A degenerate CPG primer pair (p25) was developed and successfully used for detection of all CTV isolates regardless of identifiable or unidentified CTV genotypes. This primer pair served as a positive control in reactions with six sets of GSPs that were developed to specifically detect all known CTV genotypes. These GSPs successfully amplified a single band for each genotype using the S-RT-PCR assay. However, only one of the six sets of GSPs simultaneously amplified all six amplicons in H-RTPCR without producing any self or hetero dimers. This set of GSPs used for the simultaneous detection of all the known CTV genotypes is described in detail in Table 2.

Standardization of S- and multiplex RT-PCR. The expected genotype-specific amplicons were obtained from all five CTV type isolates by S-RT-PCR (Fig. 3) and by multiplex RT-PCR (Fig. 4). Two amplicons-namely, the positive control (CTVCPG; 672 bp) and the amplicon generated by each of the GSPswere found in all the samples infected with CTV. The amplicon sizes generated by GSPs for genotypes T36, B165, T3, VT, and T30 were 836, 510, 409, 302, and 206 bp, respectively (Fig. 3). The conventional and Multiplex-PCR Master Mix which con- tained PCR buffer, dNTPs, $\mathrm{MgCl}_{2}$, and Taq DNA polymerase was used according to the manufacturer. The multiplex RT-PCR was standardized for the reliable detection of specified CTV genotypes by changing the parameters previously used for S-RT-PCR. Standardization of the different types of multiplex RT-PCR was performed using an equal volume of pooled cDNAs from isolates of known genotype in all possible combinations. The total concentration of GSPs was decreased from 0.4 to $0.2 \mu \mathrm{M}$ and the durations of the annealing and extension steps were increased from 30 to $90 \mathrm{~s}$ (at $57^{\circ} \mathrm{C}$ ) and from 45 to $90 \mathrm{~s}$ (at $72^{\circ} \mathrm{C}$ ), respectively. There are 26 possible combinations of CTV mixed infections (Fig. 4). Combination analysis (using the formula ${ }^{\mathrm{n}} C_{\mathrm{r}}=$ $n ! / r ![n-r]$ !, for the number of possible combinations of $r$ objects from a set of $n$ objects) showed that two or three CTV genotypes can co-infect healthy plants in 10 different combinations whereas four genotypes can infect in 5 possible ways.

Specific regions of the various CTV genotypes were successfully amplified in H-RT-PCR when the Qiagen Multiplex PCR Master Mix was used. No amplicons were observed when an equal concentration of total RNA from the healthy citrus seedlings was used as template for S- and H-RT-PCR. When the PCR master mix for S-RT-PCR was used for H-RT-PCR, inconsistent results were obtained (data not shown). For example, the T36, T30, and VT genotypes failed to amplify when pooled cDNA containing all genotypes was used for H-RT-PCR with the S-RTPCR buffer system. Therefore, reaction conditions were modified for H-RT-PCR as described above.

Sensitivity limits of S- and H-RT-PCR. The detection limits of the S- and H-RT-PCR were compared. Positive results were obtained in S-RT-PCR at the dilution of cDNA $10^{-5}$ for genotype B165; $10^{-4}$ for T30, VT, and CPG; and $10^{-3}$ for T3 and T36 (Fig. $5 \mathrm{~A}$ to $\mathrm{F})$. In H-RT-PCR, positive detections were found up to $10^{-5}$ for B165, VT, and CPG; $10^{-4}$ for T30 and T36; and $10^{-3}$ for T3

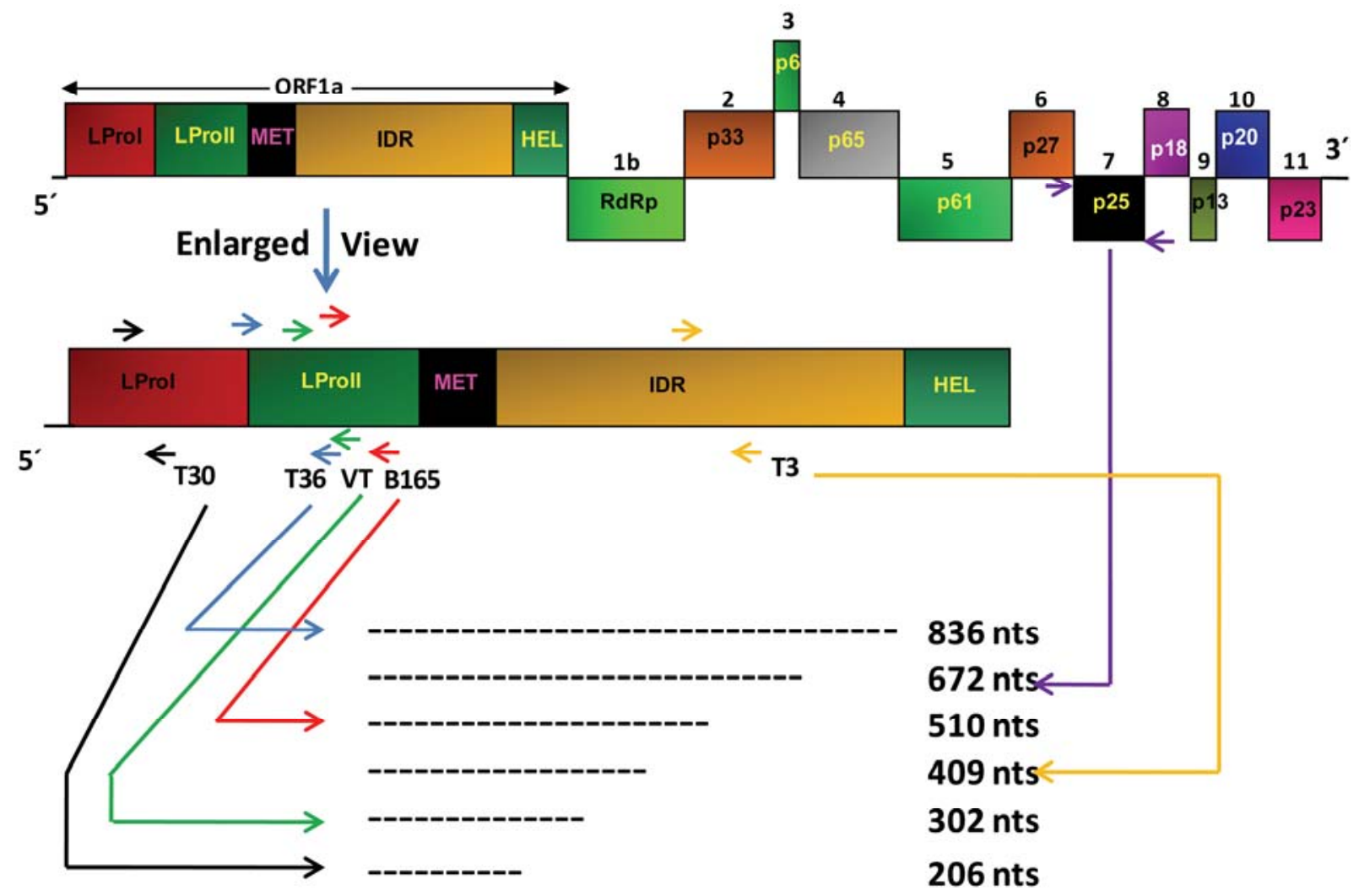

Fig. 1. Graphical representation of the genomic structure of the Citrus tristeza virus (CTV). Rectangular boxes indicate open reading frames and are numbered according to Karasev et al. (22). Arrowed areas are the locations of the genome regions amplified using reverse-transcriptase polymerase chain reaction (RT-PCR). Resulting amplicons are indicated by dotted lines corresponding to their size to the specific CTV genotype. The p25 major coat protein gene amplicon was used as positive control in the simplex and multiplex RT-PCR assays. 
(Fig. 5G). Thus, the detection sensitivity using H-RT-PCR increased for genotype T36 $\left(10^{-3}\right.$ to $\left.10^{-4}\right)$, VT $\left(10^{-4}\right.$ to $\left.10^{-5}\right)$, and CPG $\left(10^{-4}\right.$ to $\left.10^{-5}\right)$ but remained the same for B165, T3, and T30.

Identity of S- and H-RT-PCR amplicons. The RT-PCR amplicons from S- and H-RT-PCR were excised from the agarose gels, purified, amplified using specific primers, and sequenced to assess the specificity of the RT-PCR assays. Sequences of S- and H-RT-PCR products of all positive-control CTV genotypes and the species-specific CPG control were obtained and confirmed to be CTV sequences by comparison with CTV sequences in the NCBI GenBank. Amplicon sequences showed 98 to $100 \%$ identity to the targeted sequences of each genotype isolate.

Application of S- and H-RT-PCR for the detection of CTV genotypes from CREC and global collections. Using S- and $\mathrm{H}$ -
RT-PCR, 60 ELISA-positive CTV isolates from Florida were identified as infected with single or multiple CTV genotypes (Table 3). Among these 60 isolates, 13 were singly infected with either T36, T30, T3, or B165. No isolate was solely composed of the VT genotype. The remaining Florida CTV isolates tested had mixed infections (Table 3) containing two, three, or four genotypes. T3 and T30 (60 to 72\%) genotypes were more predominant in Florida isolates whereas VT and B165 genotypes (12 to 20\%) were less prevalent.

Genotypic profiles were determined for 24 CTV isolates originating in California, Hawaii, and Texas. The majority of these isolates, 21/24, were composed of more than one genotype. Among these 21 isolates, 10 isolates were co-infected with two and eight isolates with three identifiable CTV genotypes. Two

\begin{tabular}{|c|c|c|c|}
\hline \multicolumn{3}{|c|}{ CTV-CPG Control } & Sense Strand \\
\hline \multirow[t]{3}{*}{ Genotype } & I: & T36 & : ATGGACGACGAAACAAAGAAATTGAAGA \\
\hline & & Qaha & $: \ldots \ldots \ldots \ldots \ldots \ldots \ldots \ldots \ldots \ldots \ldots \ldots$ \\
\hline & & Mexican-CTV & $: \ldots \ldots \ldots \ldots \ldots \ldots \ldots \ldots \ldots \ldots$ \\
\hline \multirow[t]{2}{*}{ Genotype } & II : & T30 & 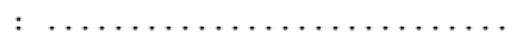 \\
\hline & & T385 & $: \ldots \ldots \ldots \ldots \ldots \ldots \ldots \ldots \ldots \ldots$ \\
\hline \multirow[t]{4}{*}{ Genotype } & III: & VT & $: \ldots \ldots \ldots \ldots$ G. \\
\hline & & SY568 & $: \ldots \ldots \ldots \ldots \ldots \ldots \ldots \ldots \ldots \ldots$ \\
\hline & & NUagA & $: \ldots \ldots \ldots \ldots \ldots \ldots \ldots \ldots \ldots \ldots$ \\
\hline & & T318A & $: \ldots \ldots \ldots \ldots \ldots \ldots \ldots \ldots \ldots \ldots$ \\
\hline \multirow[t]{2}{*}{ Genotype } & IV: & B165 & $: \ldots \ldots \ldots \ldots \ldots \ldots \ldots \ldots \ldots$ \\
\hline & & $\mathrm{NZ}-\mathrm{B} 18$ & $: \ldots \ldots \ldots \ldots \ldots \ldots \ldots \ldots \ldots \ldots$ \\
\hline \multirow[t]{2}{*}{ Genotype } & v: & T3 & $: \ldots \ldots \ldots \ldots \ldots \ldots \ldots \ldots \ldots$ \\
\hline & & NZ-M16 & $: \ldots \ldots \ldots \ldots$ G. \\
\hline
\end{tabular}

Antisense Strand ${ }^{a}$

T36 genotype specific

$\begin{array}{ll}\text { Genotype I: } & \begin{array}{l}\text { T36 } \\ \text { Qaha } \\ \text { Mexican-CTV } \\ \text { Genotype II: }\end{array} \text { T30 } \\ \text { T385 } \\ \text { Genotype III: } & \text { VT } \\ & \text { NUagA } \\ & \text { SY568 } \\ & \text { T318A } \\ \text { Genotype IV: } & \text { B165 } \\ & \text { NZ-B18 } \\ \text { Genotype V: } & \text { NZ-M16 }\end{array}$

TTCCCTAGGTCGGATCCCGAGTATA

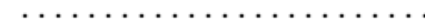

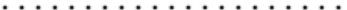

AA.T.T. . . . . . . . .

AA.T.T. . . . . . . . . .

AA.T.T.C. . .A.A. . .

AA.T.T.C....A.A. . .

AA.T.T.C....A. . . . .

AA.T.T.C. . .A. .A....

CAAT.C...A.A. . . . . .

CAAT. . . .A.A. .A. . . .

.A.T.C. . . .C.G. . .

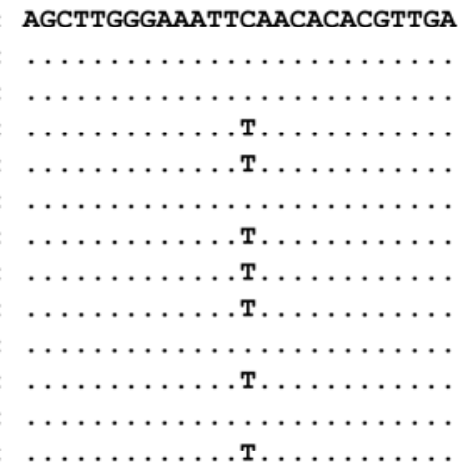

TAACAAGTGTGTCACTTCCCGGTTTG

$\ldots \ldots \ldots \ldots$. $\ldots \ldots \ldots \ldots$

$\ldots \ldots \ldots \ldots$

…A.C. . . . T. .A.

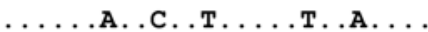

…............

…………..

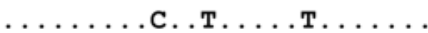

.................

С...............

С.................

...... T. . . . . . . .

T30 genotype specific

\begin{tabular}{|c|c|c|c|c|}
\hline Genotype & II : & T30 & : & TGTTGCGAAACTAGTTGACCCTACTG \\
\hline & & T385 & : & $\ldots \ldots \ldots \ldots \ldots \ldots \ldots \ldots \ldots$ \\
\hline Genotype & III: & VT & : & C...AT. ............. \\
\hline & & NUagA & : & 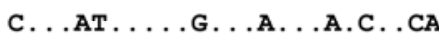 \\
\hline & & SY568 & : & C...AT............. \\
\hline & & T318A & : & C. .САT.G..G...A. . . C. . \\
\hline Genotype & IV: & B165 & : & C. .GAT...C.G. .GA...A. . \\
\hline & & $\mathrm{NZ}-\mathrm{B} 18$ & : & C. .GAT...C.G. .GA...A. .C \\
\hline Genotype & v: & NZ-M16 & : & C..C.A....G.....C.C \\
\hline Genotype & I: & T36 & : & WG.T.G.G.C..A.G. \\
\hline & & Qaha & & \#G.T.G.G.C...A.G. \\
\hline & & Mexican-CTV & & \#G.T.G.G.C...A.G. \\
\hline
\end{tabular}

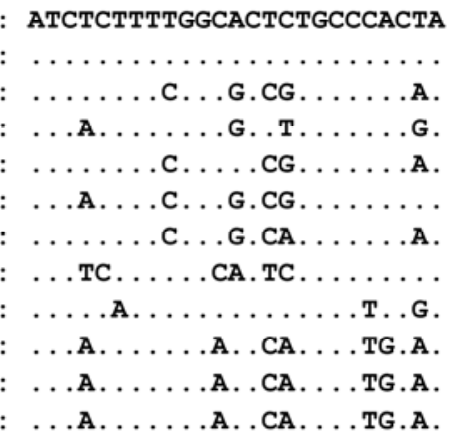

(Continued on next page)

Fig. 2. Nucleotide sequence alignment of sense and antisense genotype-specific primers for different Citrus tristeza virus (CTV) isolates; dots indicate where sequence identity occurs. All the isolates are grouped as genotype I (T36 [GenBank accession U16304], Qaha [AY340974], and Mexican CTV [DQ272579]), genotype II (T30 [AF260651] and T385 [Y18420]), genotype III (VT [U56902], SY568 [AF001623], NUagA [AB046398], and T318A [DQ151548]), genotype IV (B165 [EU076703] and NZ-B18 [FJ525436]) and genotype V (T3 partial sequence [AY285673] and NZ-M16 [EU857538]). 
isolates from Hawaii, one from California, and four from Florida had mixed infections composed of four identifiable CTV genotypes. None of the 84 isolates from the United States were composed of all five known CTV genotypes.

Genotypic profiles were determined for 91 "exotic" ELISApositive CTV isolates from 28 citrus-growing countries (excluding the United States). The distribution of the five known CTV genotypes is presented in Table 4. In all, 55 isolates contained the T36 genotype, 46 contained the VT genotype, 41 contained the T3 genotype, 19 contained the T30 genotype, and 12 contained the B165 genotype. In total, 58 of the isolates were co-infected with two or more CTV genotypes (Table 4). Only one CTV isolate, BAN-2 from India, was identified as containing all five known genotypes.
In a previous study, the multiple molecular marker (MMM) SRT-PCR assay could not identify the genotype of eight CTV isolates (17). The S- and H-RT-PCR assays reported here successfully identified seven of these eight CTV isolates as single or multiple genotype infections. These isolates were B275 from Australia (infected with T3 and T36), B282 from Bermuda (infected with T36 and VT), B66 from China (infected with T3, T36, and VT), B116 from Hawaii (infected with T3, T30, T36, and VT), B294 from Jamaica (infected with T36), B29 from Japan (infected with T36 and B165) and B249 from Venezuela (infected with T36 and VT). A genotypic profile could not be determined for the Spanish CTV isolate B159, as in the previous study (17). In addition, a genotypic profile could not be determined for isolate B301 from Puerto Rico.

$\begin{array}{ll}\text { VT genotype specific } \\ \text { Genotype III: } & \text { VT } \\ & \text { T318A } \\ & \text { NUagA } \\ & \text { SY568 } \\ \text { Genotype II: } & \text { T30 } \\ & \text { T385 } \\ \text { Genotype IV: } & \text { B165 } \\ & \text { NZ-B18 } \\ \text { Genotype V: } & \text { NZ-M16 } \\ \text { Genotype I: } & \text { T36 } \\ & \text { Qaha } \\ & \text { Mexican-CTV }\end{array}$

B165 genotype specific

$\begin{array}{ll}\text { Genotype IV: } & \text { B165 } \\ & \text { NZ-B18 } \\ \text { Genotype V: } & \text { NZ-M16 } \\ \text { Genotype III: } & \text { VT } \\ & \text { NUagA } \\ & \text { SY568 } \\ & \text { T318A } \\ \text { Genotype II: } & \text { T30 } \\ & \text { T385 } \\ \text { Genotype I: } & \text { T36 } \\ & \text { Qaha } \\ & \text { Mexican-CTV }\end{array}$

T3 genotype specific

$\begin{array}{ll}\text { Genotype V: } & \text { T3 } \\ \text { Genotype II: } & \text { T30 } \\ & \text { T385 } \\ \text { Genotype III: } & \text { VT } \\ & \text { NUagA } \\ & \text { T318A } \\ & \text { SY568 } \\ \text { Genotype IV: } & \text { B165 } \\ & \text { NZ-B18 } \\ \text { Genotype I: } & \text { T36 } \\ & \text { Qaha } \\ & \text { Mexican-CTV }\end{array}$

${ }^{\text {aa }}$ Reverse complement sequence
Sense Strand

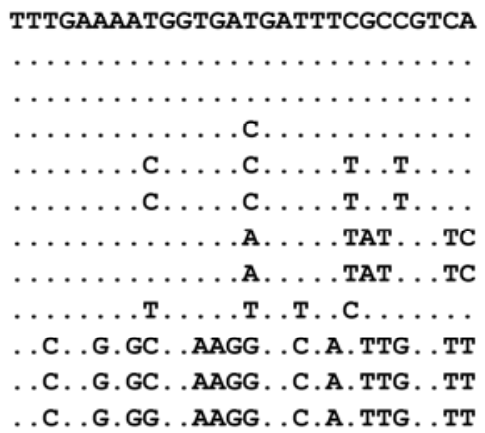

Antisense Strand ${ }^{\mathrm{a}}$

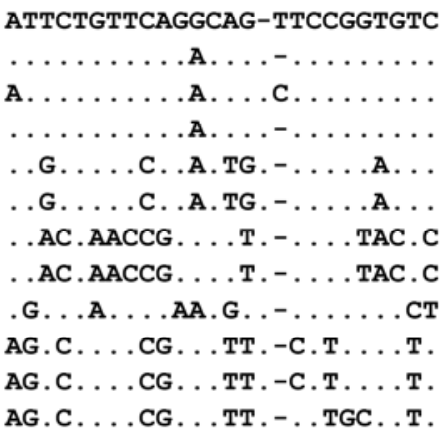

GTTAAGAAGGATCGCCATCTTGACG-TTGA .................... .G.G. . .AG. . .GTT . . CAA...... . .GCG. . . .AG. . .GTT. .CGA.T.-. . .

. GCG. . . T-C. .GTT. .CGA.T.G. . .

. .GCG.....AG. . .GTT. .CGA.T.-...

. .GCG. . . .AG. . .GTT . .CGA.T.-. . .

. .GCG. . . A AG. . AATT . .CGA. . - . .

. .GCG. . . . AG. .AATT. .CGA.......

. . CC. . . .GCTA.GT. .CC. . T.-...

C. .CC. . . GCTA.GT. .AA. T. - . .

...CC....GGTA.GT. .CC. .T.-..T.

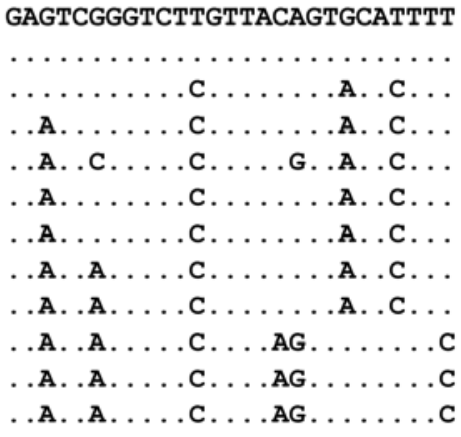

Fig. 2. (Continued from previous page.)

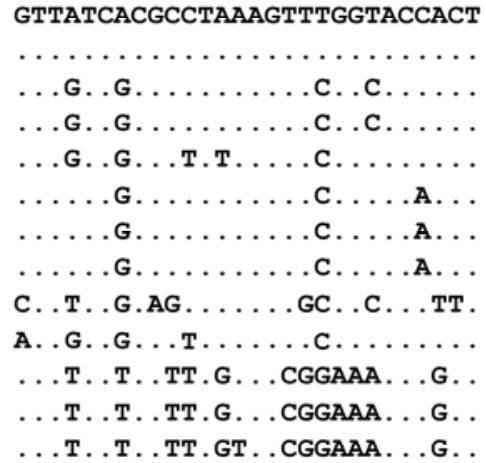

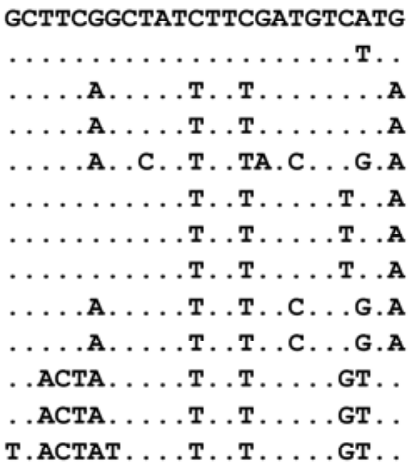




\section{DISCUSSION}

Genomic analyses of CTV isolates have recently increased the number of known CTV genotypes from three to five and, thus, CTV diagnosis must change $(16,37,39)$. Therefore, new identification and differentiation methods are required to distinguish between various CTV genotypes. Bio-indexing is useful for detailed studies of individual CTV isolates (13) but has not been used for genotyping due to the lack of correlation between phenotypic expression and genetic identification. In addition, bioindexing cannot distinguish between isolates with single- and multiple-genotype infections. Serological methods such as ELISA are useful for primary diagnostic assays of CTV infections $(10,15,31,32,33,51)$ but also cannot differentiate genotypes. The commonly used MAb, MCA-13, can serologically differentiate the T36 (DEC) genotype from the T30 (asymptomatic) genotype (33) but is unable to differentiate T36 from SP genotypes such as VT, T3, and B165. A system that combines OSP with ELISA serologically differentiates only sweet orange SP-CTV isolates from non-SP isolates (31). Genotypes have been identified by use of MMM RT-PCR $(18,19)$. However, these primers cannot be used for multiplex RT-PCR because of primer interference and overlapping amplicons.

This study describes S- and multiplex RT-PCR assays that are efficient tools for the detection and identification of all known CTV genotypes. A number of CTV genotypic isolates or strain detection assays have been reported, based on S-RT-PCR and RTqPCR utilizing various GSPs $(18,19,36,44)$. These methods successfully distinguished a maximum of four genotypes but did not have the ability to simultaneously identify these four genotypes. The recently reported CTV-B165 genotype (39) was not included in the previous studies. In this study, GSPs were designed and standardized based on the sizes of the anticipated amplicons. A major advantage of the multiplex RT-PCR technique is its capability to detect and differentiate individual CTV isolate genotypes and co-infections, if any, in a single assay. Previously reported CTV genotype-specific MMMs $(18,19)$ were used to identify T3, T30, T36, and VT genotypes using S-RT-PCR but these markers were unable to detect unidentified genotypes in single or co-infections, such as the recently discovered B165 (39). To our knowledge, this is the first report of the multiplex RT-PCR technique for simultaneous detection of all currently known CTV genotypes. This detection and identification method also would be applicable in field-based epidemiological studies.

Multiple citrus viruses, viroids, and other citrus pathogens were detected simultaneously by PCR using methods developed in previous studies $(5,21,40)$. The design and standardization of multiplex RT-PCR assays for citrus viruses belonging to different families is comparatively simpler than multiplex determination of the genotypes of the same virus. Competition among the different templates of multiple CTV genotypes and their uneven distribution in mixed infections decrease the chance of proper CTV genotype identification. In our work, six sets of GSPs were standardized for conventional S-RT-PCR, out of which only one GSP set successfully amplified all of the amplicons in multiplex RT-PCR (Table-2). Careful design of primers to avoid hairpins, self- and hetero-dimers, and competition for primers among CTV templates may account for our successful amplification of genotype-specific amplicons in H-RT-PCR. In addition, multiple RT-PCR parameters were optimized to ensure an efficient H-RTPCR. These parameters included utilizing the Qiagen Multiplex PCR Master Mix with a lower concentration of primers and longer annealing and extension times. The HotStar Taq (Qiagen) successfully amplified very low copy numbers of CTV genotype targets and prevented the formation of misprimed products and primer dimers during the multiplex reaction.

Both single- and multiple-CTV-genotype infections can be detected in a single assay using multiplex RT-PCR. In addition,
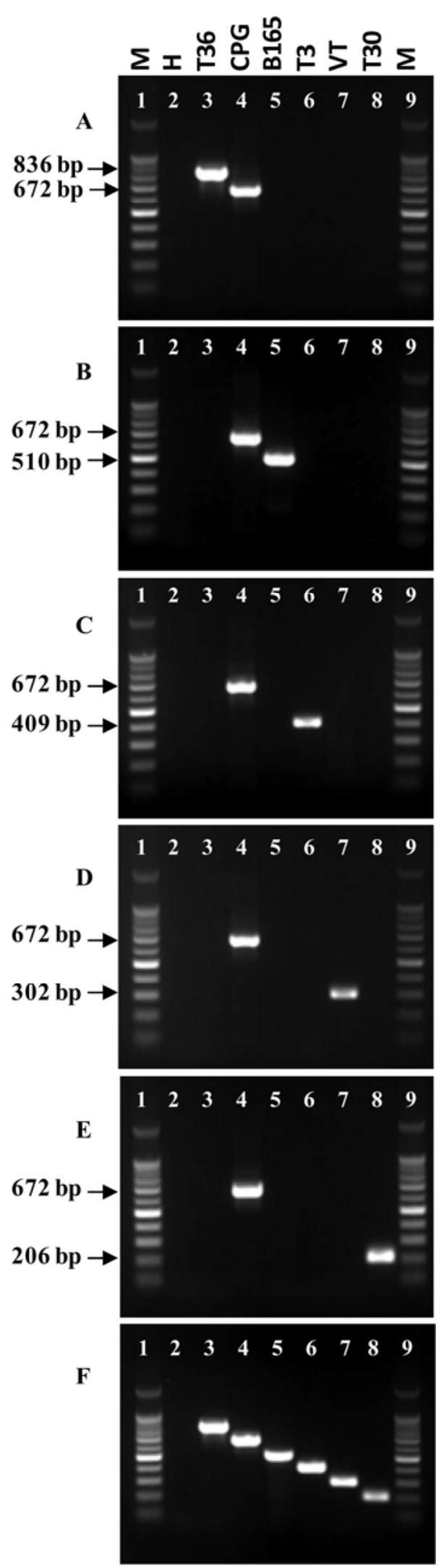

Fig. 3. Simplex reverse-transcription polymerase chain reaction (RT-PCR) amplicons obtained from A, Citrus tristeza virus (CTV)-T36 (836 bp); B, CTV-B165 (510 bp); C, CTV-T3 (409 bp); D, CTV-VT (302 bp); E, CTV-T30 (206 bp); and F, mixture of all five CTV genotypic isolates and the generic CTV coat protein gene (672 bp) (lane 4) and five genotype-specific primers (lanes 3 and 5 to 8 ). All the RT-PCR primer names are indicated at the top and the same lanes are aligned in each successive panel. Lanes 1 and 9: 100-bp molecular marker from healthy citrus seedlings. Lane 2: total RNA was used as the negative control. 
the limit of sensitivity for detection of CTV RNA infection in either single- of mixed-genotype infections has been standardized. It is significant that, when equal concentrations of RNA were tested in a dilution series, the detection sensitivity for the multiplex RT-PCR was either equal to or better than the S-RT$\mathrm{PCR}$, so that there was no loss of sensitivity in the H compared with the $\mathrm{S}$ assays. Because these standards were developed from total RNA, the proportion of virus to citrus RNA may vary between samples, which may be the possible reason for the lower sensitivity in detection of genotype T3.

Infections of CTV with multiple genotypes have been identified previously, and one genotype is often predominant in a population $(36,38,41)$. Double or multiple infections of different CTV genotypes within citrus hosts are considered to be common. Previous methods for genotyping CTV isolates required serial-specific SRT-PCR and subsequent sequencing. In this study, the genotypic composition of $175 \mathrm{CTV}$ isolates was determined by the new multiplex RT-PCR detection system. The results of serial S-RTPCR assays and the multiplex RT-PCR assay were well correlated, demonstrating the improved efficiency of the new multiplex RT-PCR system and also showing that multiplex RT-PCR can effectively detect multiple CTV genotype infections in citrus without sequencing.

Analyses of Florida CTV isolates revealed that the genotypes T3 and T30 were predominant in mixed infections. In total, 47 CTV isolates were composed of two, three, or four genotypes (Table 3). Among these isolates, 43 included T3 and T30 geno- types. T36 infections were predominant in triple and quadruple genotype infections with T3 and T30. Due to the small number of samples from California, Hawaii, and Texas, the array of CTV genotypes found may be incomplete for these states. As was observed with the Florida isolates, $50 \%$ of the isolates from California, Hawaii, and Texas with multiple genotypes contained T3 and T30 genotypes in either double-, triple-, or quadruple-genotype co-infections. The VT genotype was more often found in mixed infections with T3 and T30 rather than with the T36 and B165 genotypes.

The S- and multiplex RT-PCR assays revealed that $75 \%$ of the EPCC isolates contained one or two CTV genotypes. Genotypes T3 and T30 were predominant in the collection of U.S. isolates of CTV, which may represent a defined "subset" of the CTV genotypes, In contrast, the "exotic" CTV isolates did not follow any specific pattern of mixed genotypic infections. Citrus-growing countries such as China, India, Indonesia, Japan, and Taiwan have a greater diversity of Citrus spp. than is found in the United States (48), and four to five identifiable CTV genotypes were detected in single CTV isolates from these countries, except China (Table 4). The accumulation of multiple CTV genotypes may be favored by conditions such as the prolonged existence of citrus trees in the field, long-term persistent infections, and transmission of CTV by aphid vectors $(38,52)$. The present analyses provide an approximation of the distribution of different CTV genotypes in many citrus-growing countries. The approximation is, of course, limited. The EPCC CTV collection may be geographically biased and may not reflect the overall distribution and incidence of CTV
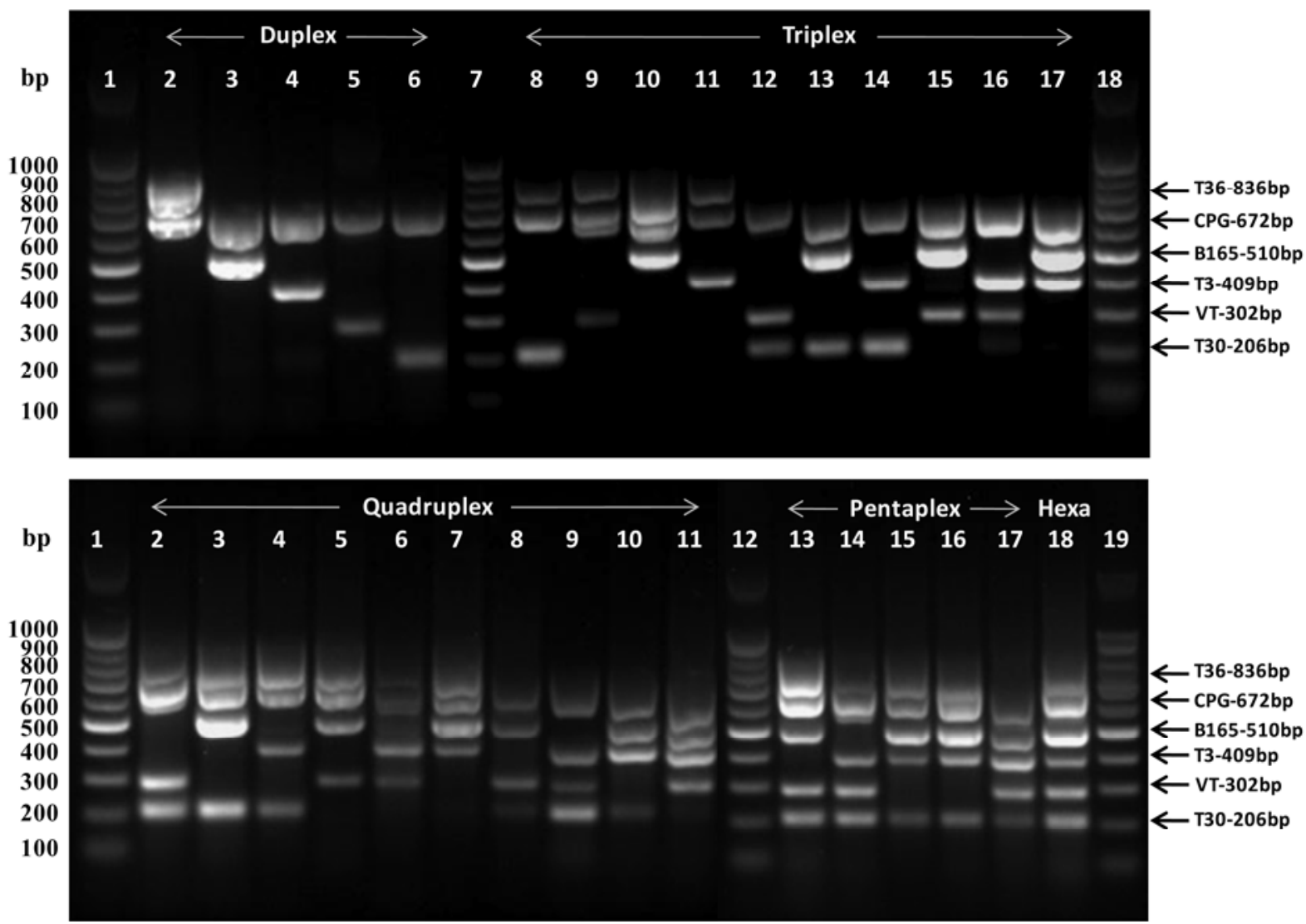

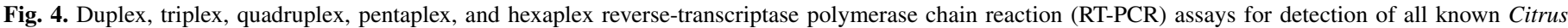

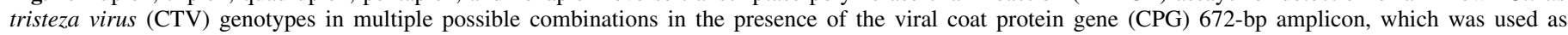

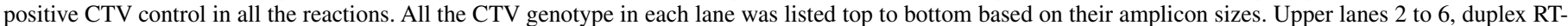

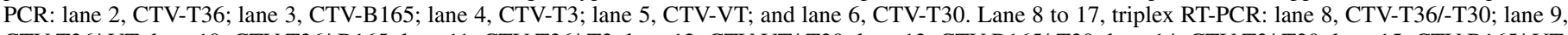

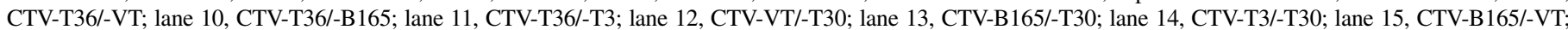

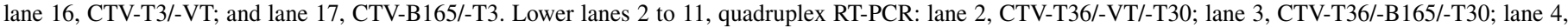

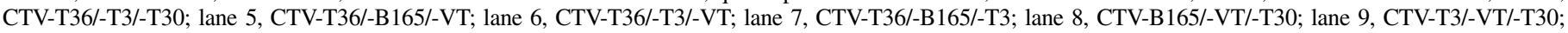

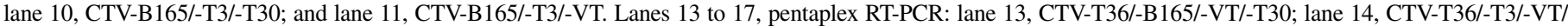

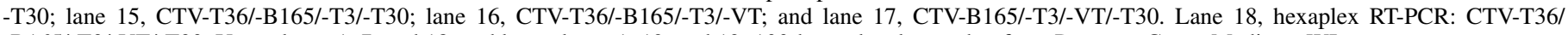
-B165/-T3/-VT/-T30. Upper lanes 1, 7, and 18, and lower lanes 1, 12, and 19: 100-bp molecular marker from Promega Corp., Madison, WI. 
genotypes worldwide (19); however, this is the only location where such a worldwide collection exists.

In the present study, a major advance to enable routine diagnosis and differentiation of known CTV genotypes was devel- oped. Regardless of geographical origin, two or more genotypes are often found under field conditions and, therefore, the present two-step multiplex RT-PCR protocol is needed for the detection and identification of CTV genotypes. This precise tool for CTV

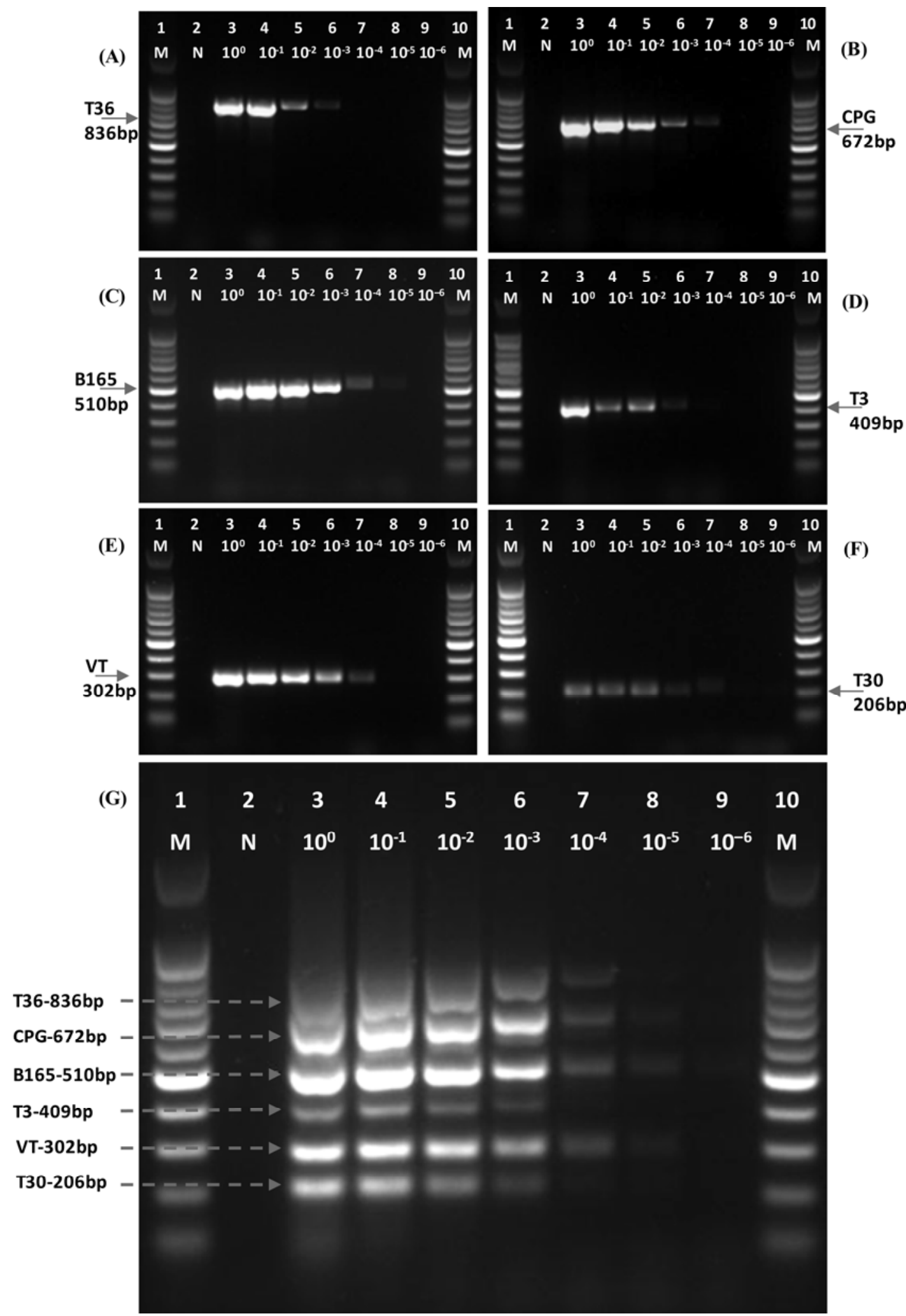

Fig. 5. Specific primer sensitivity evaluation for simplex and hexaplex reverse-transcription polymerase chain reaction (RT-PCR). A, Citrus tristeza virus (CTV)T36; B, coat protein gene positive from CTV-infected plants; C, CTV-B165; D, CTV-T3; E, CTV-VT; F, CTV-T30; and G, hexaplex RT-PCR: mixed infected CTV genotypic isolates. Detection sensitivity of the simplex and hexaplex RT-PCR for all of the above-mentioned six isolates was tested using 10-fold serial dilution. Total RNA (200 ng/ $\mu \mathrm{l}$ ) from different CTV genotype-infected plants was used to make $50 \mu \mathrm{l}$ of cDNA preparation that was used as standard concentration $10^{0}$ and diluted up to $10^{-6}$. Lanes (1 and 10): 100-bp molecular marker from Promega Corp. (Madison, WI); lane 2, healthy seedlings used as negative control (N); lanes 3 to 9 , serial dilution of positive control plant $10^{0}$ to $10^{-6}$ used as template for each RT-PCR assay. 
genotype detection and identification should be useful in the development of CTV-free or -resistant citrus plants. The five genotypes encompassed by our multiplex RT-PCR assay are the only genotypes currently described. However, we note that two
ELISA- and RT-PCR-positive CTV isolates could not be assigned to any known genotype. This suggests that sequencing of those two isolates is needed to determine whether they are new genotypes or variants of an existing genotype. The recent publication

TABLE 3. Presence of identifiable Citrus tristeza virus (CTV) genotypes in different citrus-growing states in the United States, determined by simplex and multiplex reverse-transcription polymerase chain reaction analysis

\begin{tabular}{|c|c|c|c|c|c|c|c|c|c|c|c|c|c|}
\hline \multirow[b]{2}{*}{ States } & \multirow[b]{2}{*}{ CTV isolates ${ }^{\mathrm{a}}$} & \multirow{2}{*}{$\frac{\text { Control }}{\text { CTV-CPG }}$} & \multicolumn{5}{|c|}{ Genotypes detected } & \multicolumn{6}{|c|}{ Presence of CTV genotype in single and mixed infection } \\
\hline & & & T36 & $\mathrm{T} 30$ & VT & B165 & $\mathrm{T} 3$ & One & Two & Three & Four & Five & Unassigned \\
\hline California & 15 & 15 & 3 & 10 & 8 & 2 & 13 & 1 & 6 & 7 & 1 & 0 & 0 \\
\hline Florida & 60 & 60 & 35 & 43 & 12 & 7 & 36 & 13 & 20 & 23 & 4 & 0 & 0 \\
\hline Hawaii & 4 & 4 & 2 & 2 & 3 & 1 & 4 & 0 & 2 & 0 & 2 & 0 & 0 \\
\hline Texas & 5 & 5 & 2 & 2 & 2 & 2 & 1 & 2 & 2 & 1 & 0 & 0 & 0 \\
\hline Total & 84 & 84 & 42 & 57 & 25 & 12 & 54 & 16 & 30 & 31 & 7 & 0 & 0 \\
\hline
\end{tabular}

${ }^{a}$ All the California and Hawaii CTV isolates were obtained from the Exotic Pathogens of Citrus Collection (EPCC), Beltsville, MD. Isolates included those from (i) California: B4, B5, B6, B151, B152, B334, B348, B349, B350, B351, B352, B353, B354, B355, and B356; (ii) Hawaii: B54, B116, B119, and B120; and (iii) Texas (CTV isolates were provided by Dr. John da Graca from Texas A\&M University, Kingsville): TX-1, TX-2, TX-3, TX-4, and TX-C. In addition, 2 Florida CTV isolates from EPCC (B384 and B396) and 58 Florida isolates (AZ-4, AZ-6, AZ-8, AZ-10, AZ-11, AZ-14, AZ-17, AZ-20, AZ-21, AZ-22, FL53, FL86, FL90, FL104, FL128, FL139, FL145, FL166, FL193, FL202, FL208, FL209, FL230, FL251, FL302, FS043, FS252, FS257, FS317, FS480, FS577, FS625, FS627, FS627/T68G, FS627/T68K, FS627/T68.1C, FS627/T68.1E, FS627/T68.1G, FS627/T68.1J, T3, T4, T25, T26, T30, T36, T30-36, T49.1, T50A, T55, T59, T66, T67, T67.1, T68, T68.1, T69, T69.1, and T380) were collected from greenhouse plant materials at the University of Florida, Citrus Research and Education Center, Lake Alfred.

TABLE 4. Presence of identifiable and unassigned Citrus tristeza virus (CTV) genotypes from multiple citrus-growing countries determined by both simplex and multiplex reverse-transcription polymerase chain reaction analysis

\begin{tabular}{|c|c|c|c|c|c|c|c|c|c|c|c|c|c|}
\hline \multirow[b]{2}{*}{ Continent, countries } & \multirow[b]{2}{*}{$\mathrm{CTV}^{\mathrm{a}}$} & \multirow{2}{*}{$\frac{\text { Control }}{\text { CTV-CPG }}$} & \multicolumn{5}{|c|}{ Genotypes detected } & \multicolumn{6}{|c|}{ Presence of CTV genotype in single and mixed infection } \\
\hline & & & $\mathrm{T} 36$ & $\mathrm{~T} 30$ & VT & B165 & $\mathrm{T} 3$ & One & Two & Three & Four & Five & Unassigr \\
\hline \multicolumn{14}{|l|}{ Asia } \\
\hline China & 5 & 5 & 5 & 0 & 1 & 1 & 3 & 2 & 1 & 2 & 0 & 0 & 0 \\
\hline India & 11 & 11 & 4 & 2 & 10 & 2 & 3 & 5 & 4 & 1 & 0 & 1 & 0 \\
\hline Indonesia & 1 & 1 & 1 & 0 & 1 & 1 & 1 & 0 & 0 & 0 & 1 & 0 & 0 \\
\hline Israel & 4 & 4 & 1 & 1 & 3 & 0 & 2 & 2 & 1 & 1 & 0 & 0 & 0 \\
\hline Japan & 4 & 4 & 3 & 0 & 1 & 2 & 2 & 2 & 1 & 0 & 1 & 0 & 0 \\
\hline Malaysia & 1 & 1 & 0 & 0 & 1 & 0 & 1 & 0 & 1 & 0 & 0 & 0 & 0 \\
\hline Philippines & 2 & 2 & 0 & 1 & 2 & 0 & 2 & 0 & 1 & 1 & 0 & 0 & 0 \\
\hline Taiwan & 4 & 4 & 3 & 0 & 2 & 1 & 2 & 2 & 1 & 0 & 1 & 0 & 0 \\
\hline Thailand & 1 & 1 & 0 & 0 & 1 & 0 & 0 & 1 & 0 & 0 & 0 & 0 & 0 \\
\hline Turkey & 1 & 1 & 0 & 1 & 0 & 0 & 1 & 0 & 1 & 0 & 0 & 0 & 0 \\
\hline \multicolumn{14}{|l|}{ Africa } \\
\hline South Africa & 3 & 3 & 3 & 0 & 2 & 2 & 1 & 0 & 2 & 0 & 1 & 0 & 0 \\
\hline Tanzania & 1 & 1 & 1 & 0 & 0 & 1 & 0 & 0 & 1 & 0 & 0 & 0 & 0 \\
\hline \multicolumn{14}{|l|}{ Europe } \\
\hline Corsica & 3 & 3 & 2 & 1 & 1 & 0 & 0 & 2 & 1 & 0 & 0 & 0 & 0 \\
\hline Spain & 7 & 7 & 2 & 4 & 1 & 0 & 3 & 2 & 4 & 0 & 0 & 0 & 1 \\
\hline \multicolumn{14}{|l|}{ Oceania } \\
\hline Australia & 8 & 8 & 7 & 0 & 1 & 0 & 1 & 7 & 1 & 0 & 0 & 0 & 0 \\
\hline New Zealand & 6 & 6 & 6 & 0 & 2 & 0 & 1 & 2 & 4 & 0 & 0 & 0 & 0 \\
\hline \multicolumn{14}{|l|}{ South America } \\
\hline Brazil & 4 & 4 & 4 & 1 & 3 & 1 & 3 & 1 & 0 & 2 & 1 & 0 & 0 \\
\hline Colombia & 2 & 2 & 2 & 0 & 2 & 0 & 1 & 0 & 1 & 1 & 0 & 0 & 0 \\
\hline Peru & 4 & 4 & 3 & 0 & 3 & 0 & 4 & 0 & 2 & 2 & 0 & 0 & 0 \\
\hline Venezuela & 3 & 3 & 1 & 1 & 2 & 0 & 1 & 1 & 2 & 0 & 0 & 0 & 0 \\
\hline \multicolumn{14}{|l|}{ North America } \\
\hline Belize & 1 & 1 & 0 & 1 & 0 & 0 & 1 & 0 & 1 & 0 & 0 & 0 & 0 \\
\hline Bermuda & 2 & 2 & 2 & 0 & 1 & 0 & 0 & 1 & 1 & 0 & 0 & 0 & 0 \\
\hline Costa Rica & 2 & 2 & 0 & 1 & 1 & 1 & 1 & 0 & 2 & 0 & 0 & 0 & 0 \\
\hline Cuba & 2 & 2 & 1 & 2 & 1 & 0 & 2 & 0 & 0 & 2 & 0 & 0 & 0 \\
\hline Dominican & 3 & 3 & 0 & 2 & 2 & 0 & 3 & 0 & 3 & 0 & 0 & 0 & 0 \\
\hline \multicolumn{14}{|l|}{ Republic } \\
\hline Jamaica & 2 & 2 & 2 & 0 & 0 & 0 & 0 & 2 & 0 & 0 & 0 & 0 & 0 \\
\hline Puerto Rico & 3 & 3 & 1 & 1 & 1 & 0 & 1 & 0 & 2 & 0 & 0 & 0 & 1 \\
\hline Trinidad & 1 & 1 & 1 & 0 & 1 & 0 & 1 & 0 & 0 & 0 & 1 & 0 & 0 \\
\hline United States & 84 & 84 & 42 & 57 & 25 & 12 & 54 & 16 & 30 & 31 & 7 & 0 & 0 \\
\hline Total & 175 & 175 & 97 & 76 & 71 & 24 & 95 & 48 & 68 & 43 & 13 & 1 & 2 \\
\hline
\end{tabular}

a All the global CTV isolates were obtained from the Exotic Citrus Disease Collection, Beltsville, MD. Isolates included those from (i) China: B61, B66, B67, B267, and B270; (ii) India: B165, B166, B167, B184, B194, B195, B219, B222, B226, B227, and BAN-2; (iii) Indonesia: B255; (iv) Israel: B25, B26, B79, and B395; (v) Japan: B29, B31, B186, and B190; (vi) Malaysia: B278; (vii) Philippines: B136 and B143; (viii) Taiwan: B211, B233, B253, and B279; (ix) Thailand: B257; (x) Turkey: B337; (xi) South Africa: B7, B8, and B47; (xii) Tanzania: B216; (xiii) Corsica: B192, B192N, and B358; (xiv) Spain: B32, B33, B35, B53, B159, B160, and B361; (xv) Australia: B155, B187, B247, B275, B369, B372, B373, and B374; (xvi) New Zealand: CQ83, CQ283, CQ285, CQ291, NZ-KD-8, and NZKD-11; (xvii) Brazil: B12, B13, B16, and B77; (xviii) Colombia: B131 and B229; (xix) Peru: B133, B135, B412, and B413; (xx) Venezuela: B248, B249, and B400; (xxi) Belize: B277; (xxii) Bermuda: B281 and B282; (xxiii) Costa Rica: B276 and B322; (xxiv) Cuba: B304 and B310; (xxv) Dominican Republic: B296, B297, and B408; (xxvi) Jamaica: B294 and B302; (xxvii) Puerto Rico: B300, B301, and B386; (xxviii) Trinidad: B340; and (xxix) the United States: All CTV isolates from California, Hawaii, Texas, and Florida were included in Table 3. 
of the complete genome sequence of five New Zealand CTV resistance-breaking isolates showed them to be T36-like in ORF1a. Further phylogenetic analyses of the $3^{\prime}$ terminal half region (ORF2-11) showed them to be an unidentified recombinant genotype (26). Two of these New Zealand isolates, NZRBM17 (FJ525435) and -TH30 (FJ525434), contained sequences identical to the sense and antisense T36 GSPs developed in our study and should be detected. The other three New Zealand isolates-NZRB-M12 (FJ525431), -G90 (FJ525432), and -TH28 (FJ525433) - as well as two recently sequenced Hawaiian isolates-HA18-9 (GQ454869) and HA16-5 (GQ454870) —would not be detected with the T36 GSPs. Thus, new CTV genotype primers need to be developed and added following the methods outlined for this CTV multiplex RT-PCR assay.

\section{ACKNOWLEDGMENTS}

We thank C. Paul, United States Department of Agriculture (USDA) Agricultural Research Service, Molecular Plant Pathology Laboratory, Beltsville, MD, for providing the exotic CTV isolates as desiccated tissue from the Exotic Pathogens of Citrus Collection, Beltsville, MD; J. da Graca from Texas A\&M University, Kingsville, TX, for providing isolated total RNA from CTV-infecting Texas isolates; and the USDA Cooperative State Research, Education and Extension Service, Special Tristeza Grant Project 62506 for financial assistance.

\section{LITERATURE CITED}

1. Albiach-Martí, M. R., Mawassi, M., Gowda, S., Satyanarayana, T., Hilf, M. E., Shanker, S., Almira, E. C., Vives, M. C., López, C., Guerri, J., Flores, R., Moreno, P., Garnsey, S. M., and Dawson, W. O. 2000. Sequences of Citrus tristeza virus separated in time and space are essentially identical. J. Virol. 74:6856-6865.

2. Ananthakrishnan, G., Venkataprasanna, T., Roy, A., and Brlansky, R. H. 2010. Characterization of the mixture of genotypes of a Citrus tristeza virus isolate by reverse transcription-quantitative real-time PCR. J. Virol. Methods 164:75-82.

3. Ayllón, M. A., López, C., Navas-Castillo, J., Garnsey, S. M., Guerri, J., Flores, R., and Moreno, P. 2001. Polymorphism of the $5^{\prime}$ terminal region of Citrus tristeza virus (CTV) RNA: incidence of three sequence types in isolates of different origin and pathogenicity. Arch. Virol. 146:27-40.

4. Ayllón, M. A., Rubio, L., Sentandreu, V., Moya, A., Guerri, J., and Moreno, P. 2006. Variations in two gene sequences of Citrus tristeza virus after host passage. Virus Genes 32:119-128.

5. Baranwal, V. K., Majumders, S., Ahlawat, Y. S., and Singh, R. P. 2005. A novel approach for simultaneous detection of Citrus yellow mosaic virus and citrus greening bacterium by multiplex polymerase chain reaction. Indian J. Biotechnol. 4:528-533.

6. Bar-Joseph, M., Marcus, R., and Lee, R. F. 1989. The continuous challenge of Citrus tristeza virus control. Annu. Rev. Phytopathol. 27:291-316.

7. Bertolini, E., Moreno, A., Capote, N., Olmos, A., Luis, A., Vidal, E., Panadés, J. P., and Cambra, M. 2008. Quantitative detection of Citrus tristeza virus in plant tissues and single aphids by real-time RT-PCR. Eur. J. Plant Pathol. 120:177-188.

8. Bertolini, E., Olmos, A., Carmen Martínez, M., María Teresa, G., and Cambra, M. 2001. Single-step multiplex RT-PCR for simultaneous and colourimetric detection of six RNA viruses in olive trees. J. Virol. Methods 96:33-41

9. Brlansky, R. H., Damsteegt, V. D., Howd, D. S., and Roy, A. 2003. Molecular analyses of Citrus tristeza virus subisolates separated by aphid transmission. Plant Dis. 87:397-401

10. Cambra, M., Camarasa, E., Gorris, M. T., Garnsey, S. M., and Carbonell, E. 1991. Comparison of different immunosorbent assays for citrus tristeza virus (CTV) using CTV-specific monoclonal and polyclonal antibodies. Pages 38-45 in: Proc. 11th Conf. Int. Organ. Citrus Virol. R. H. Brlansky, R. F. Lee, and L.W. Timmer, eds. IOCV, Riverside, CA.

11. Dovas, C. I., and Katis, N. I. 2003. A spot nested RT-PCR method for the simultaneous detection of members of the Vitivirus and Foveavirus genera in grapevine. J. Virol. Methods 170:99-106.

12. Gambino, G., and Gribaudo, I. 2006. Simultaneous detection of nine grapevine viruses by multiplex reverse transcription-polymerase chain reaction with coamplification of a plant RNA as internal control. Phytopathology 96:1223-1229.

13. Garnsey, S. M., Civerolo, E., Gumpf, D. J., Paul, C., Hilf, M. E., Lee, R. F., Brlansky, R. H., Yokomi, R. K., and Hartung, J. S. 2005. Biological characterization of an international collection of Citrus tristeza virus (CTV) isolates. Pages 75-93 in: Proc. 16th Conf. Int. Organ. Citrus Virol. M. E. Hilf, N. Duran-Vila, and M. A. Rocha-Peña, eds. IOCV, Riverside, CA

14. Garnsey, S. M., Gumpf, D. J., Civerolo, E. L., Lee, R. F., Roistacher, C. N., Yokomi, R. K., and Bar-Joseph, M. 1987. Toward a standardized evaluation of the biological properties of citrus tristeza virus. Phytophylactica 19:151-157.

15. Garnsey, S. M., Permar, T. A., Cambra, M., and Henderson, C. T. 1993. Direct tissue blot immunoassay (DTBIA) for detection of citrus tristeza virus (CTV). Pages 39-50 in: Proc. 12th IOCV Conf. IOCV, Riverside, CA.

16. Harper S. J., Dawson, T. E., and Pearson, M. N. 2009. Complete genome sequences of two distinct and diverse Citrus tristeza virus isolates from New Zealand. Arch. Virol. 154:1505-1510.

17. Hilf, M. E., and Garnsey, S. M. 2000. Characterization and classification of Citrus tristeza virus isolates by amplification of multiple molecular markers. Pages 18-27 in: Proc. 14th Conf. Int. Organ. Citrus Virol. IOCV, IOCV, Riverside, CA.

18. Hilf, M. E., Karasev, A. V., Albiach-Martí, M. R., Dawson, W. O., and Garnsey, S. M. 1999. Two paths of sequence divergence in the citrus tristeza virus complex. Phytopathology 89:336-342.

19. Hilf, M. E., Mavrodieva, V. A., and Garnsey, S. M. 2005. Genetic marker analysis of a global collection of isolates of Citrus tristeza virus: characterization and distribution of CTV genotypes and association with symptoms. Phytopathology 95:909-917.

20. Huang, Z., Rundell, P. A., Guan, X., and Powell, C. A. 2004. Detection and isolate differentiation of Citrus tristeza virus in infected field trees based on reverse transcription-polymerase chain reaction. Plant Dis. 88:625-629.

21. Ito, T., Ieki, H., and Ozaki, K. 2002. Simultaneous detection of six citrus viroids and apple stem grooving virus from citrus plants by multiplex reverse transcription polymerase chain reaction. J. Virol. Methods 106:235-239.

22. Karasev, A. V., Boyko, V. P., Gowda, S., Nikolaeva, O. V., Hilf, M. E., Koonin, E. V., Nibblet, C. L., Cline, K., Gumpf, D. J., Lee, R. F., Garnsey, S. M., and Dawson, W. O. 1995. Complete sequence of the citrus tristeza virus RNA genome. Virology 208:511-520.

23. Lee, R. F., and Bar-Joseph, M. 2000. Tristeza. Pages 61-63 in: Compendium of Citrus Diseases. L. W. Timmer, S. M. Garnsey, and J. H. Graham, eds. American Phytopathological Society, St. Paul, MN.

24. Lorenzen, J. H., Piche, L. M., Gudmestad, N. C., Meacham, T., and Shiel, P. 2006. A multiplex PCR assay to characterize Potato virus $Y$ isolates and identify strain mixtures. Plant Dis. 90:935-940.

25. Mawassi, M., Mietkiewska, E., Gofman, R., Yang, G., and Bar-Joseph, M. 1996. Unusual sequence relationship between two isolates of citrus tristeza virus. J. Gen. Virol. 77:2359-2364.

26. Melzer, M. J., Wayne, B. B., Diane, M. S., Stephen, F., Dennis G., and John, S. H. 2010. Genetic diversity and evidence for recent modular recombination in Hawaiian Citrus tristeza virus. Virus Genes. 40:111-118.

27. Moreno, P., Ambros, S., Albiach-Marti, M. R., Guerri, J., and Pena, L. 2008. Citrus tristeza virus: a pathogen that changed the course of the citrus industry. Mol. Plant Pathol. 9:251-268.

28. Nicholas, K. B., and Nicholas, H. B., Jr. 1997. GeneDoc: a tool for editing and annotating multiple sequence alignments. www.psc.edu/ biomed/genedoc

29. Nie, X., and Singh, R. P. 2002. A new approach for the simultaneous differentiation of biological and geographical strains of Potato virus $Y$ by uniplex and multiplex RT-PCR. J. Virol. Methods 104:41-54.

30. Nie, X., and Singh, R. P. 2003. Specific differentiation of recombinant PVY (N:O) and PVY(NTN) isolates by multiplex RT-PCR. J. Virol. Methods 113:69-77.

31. Nikolaeva, O. V., Karasev, A. V., Garnsey, S. M., and Lee, R. F. 1998. Serological differentiation of citrus tristeza virus isolates causing stem pitting in sweet orange. Plant Dis. 82:1276-1280.

32. Nolasco, G., Santos, C., Silva, G., and Fonseca, F. 2009. Development of an asymmetric PCR-ELISA typing method for Citrus tristeza virus based on the coat protein gene. J. Virol. Methods 155:97-108.

33. Permar, T. A., Garnsey, S. M., Gumpf, D. J., and Lee, R. F. 1990. A monoclonal antibody which discriminates strains of citrus tristeza virus. Phytopathology 80:224-228.

34. Rocha-Pena, M. A., Lee, R. F., Lastra, R., Niblett, C. L., Ochoa-Corona, F. M., Garnsey, S. M., and Yokomi, R. K. 1995. Citrus tristeza virus and its aphid vector Toxoptera citricida. Plant Dis. 79:437-445.

35. Roistacher, C. N., and Moreno, P. 1991. The worldwide threat from destructive isolates of citrus tristeza virus-a review. Pages 7-19 in: Proc. 11th Conf. Int. Organ. Citrus Virol. IOCV, Riverside, CA.

36. Roy, A., and Brlansky, R. H. 2004. Genotype classification and molecular evidence for the presence of mixed infections in Indian Citrus tristeza virus isolates. Arch. Virol. 149:1911-1929. 
37. Roy, A., and Brlansky, R. H. 2006. Genomic sequence of Citrus tristeza virus from India represents a new genotype.(Abstr.) Phytopathology 96:S101.

38. Roy, A., and Brlansky, R. H. 2009. Population dynamics of a Florida Citrus tristeza virus isolate and aphid-transmitted subisolates: identification of three genotypic groups and recombinants after aphid transmission. Phytopathology 99:1297-1306.

39. Roy, A., and Brlansky, R. H. 2010. Genome analysis of an orange stem pitting Citrus tristeza virus isolate reveals a novel recombinant genotype. Virus Res. 151(2):118-130.

40. Roy, A., Fayad, A., Barthe, G., and Brlansky, R. H. 2005. A multiplex polymerase chain reaction method for reliable, sensitive and simultaneous detection of multiple viruses in citrus trees. J. Virol. Methods 129:47-55.

41. Roy, A., Manjunath, K. L., and Brlansky, R. H. 2005. Assessment of sequence diversity in the $5^{\prime}$ terminal region of Indian Citrus tristeza virus isolates. Virus Res. 113:132-142.

42. Rubio, L., Ayllón, M. A., Guerri, J., Pappu, H., Niblett, C., and Moreno, P. 1996. Differentiation of citrus tristeza closterovirus (CTV) isolates by single-strand conformation polymorphism analysis of the coat protein gene. Ann. Appl. Biol. 129:479-489.

43. Ruiz-Ruiz, S., Moreno, P., Guerri, J., and Ambrós, S. 2007. A real-time RT-PCR assay for detection and absolute quantitation of Citrus tristeza virus in different plant tissues. J. Virol. Methods 145:96-105.

44. Ruiz-Ruiz, S., Moreno, P., Guerri, J., and Ambrós, S. 2009. Discrimination between mild and severe Citrus tristeza virus isolates with a rapid and highly specific real-time reverse transcription-polymerase chain reaction method using TaqMan LNA probes. Phytopathology 99:307-315.
45. Sánchez-Navarro, J. A., Aparicio F., Herranz, M. C., Minafra, A., Myrta, A., and Pallás, V. 2005. Simultaneous detection and identification of eight stone fruit viruses by one-step RT-PCR. Eur. J. Plant Pathol. 111:77-84.

46. Sambade, A., López, C., Rubio, L., Flores, R., Guerri, J., and Moreno, P. 2003. Polymorphism of a specific region in the gene p23 of Citrus tristeza virus allows differentiation between mild and severe isolates. Arch. Virol. 148:2281-2291.

47. Saponari, M., Manjunath, K. L., and Yokomia, R. K. 2008. Quantitative detection of Citrus tristeza virus in citrus and aphids by real-time reverse transcription-PCR (TaqMan). J. Virol. Methods 147:43-53.

48. Swingle, W. T., and Reece, P. C. 1967. The botany of citrus and its wild relatives. Pages 190-430 in The Citrus Industry, Vol. 1 (rev). W. Reuther, H. J. Webber, and L. D. Batchelor, eds. University of California Press.

49. Thompson, J. D., Gibson, T. J., Plewniak, F., Jeanmougin, F., and Higgins, D. G. 1997. The Clustal X windows interface: flexible strategies for multiple sequence alignment aided by quality analysis tools. Nucleic Acids Res. 24:4876-4882.

50. Uga, H., and Tsuda, S. 2005. A one step reverse transcription-polymerase chain reaction system for the simultaneous detection and identification of multiple tospovirus infection. Phytopathology 95:166-171.

51. Vela, C., Cambra, M., Cortés, E., Moreno, P., Miguet, S. G., Pérez de San Román, C., and Sanz, A. 1986. Production and characterisation of monoclonal antibodies specific for citrus tristeza virus and their use for diagnosis. J. Gen. Virol. 67:91-96.

52. Weng, Z., Barthelson, R., Gowda, S., Hilf, M. E., Dawson, W. O., Galbraith, D. W., and Xiong, Z. 2007. Persistent infection and promiscuous recombination of multiple genotypes of an RNA virus within a single host generate extensive diversity. PLoS One 2(9):e917. 